\title{
URBANISTINĖS PLĖTROS VALSTYBINIO VALDYMO PROBLEMOS
}

\author{
Gintautas Tiškus
}

\begin{abstract}
Santrauka. Urbanizacija yra socialinis procesas, pasireiškiantis miestų reikšmės visuomenės raidai didejjimu. Urbanizaciją lemia objektyvi būtinybe koncentruoti ịvairias materialinės ir dvasinės veiklos formas ir rūšis. Ji intensyvina ir efektyvina socialinius procesus, nes dideliuose miestuose socialinių, politinių, ekonominių ir mokslinių techninių veiksnių, kultūrinių tradicijų, ̦vairių gyventojų sluoksnių sąveika didžiausia. Šiems sudètingiems procesams valdyti būtina sukurti veiksmingą urbanistinès plètros procese dalyvaujančiu struktūrų sistemą, kuri peržengtų atskirų miestų ir kaimo vietovių plètros problemas ir spręstų visos urbanistinès sistemos vystymo ilgalaikẻje perspektyvoje klausimus. Ministerijos, i̇gyvendindamos sektorines politikas, turi daug aiškiau suvokti šių politikų svarbą urbanizacijos procesams, veiksmai turi būti koordinuoti, kad papildytų vieni kitus, o ne prieštarautų vieni kitiems.
\end{abstract}

Reikšminiai žodžiai: urbanistinè plètra, valstybinis valdymas, teritorijų planavimas.

\section{Ivadas}

Urbanizacija yra socialinis procesas, pasireiškiantis miestų reikšmès visuomenès raidai didejjimu. Urbanizacijos procese galima išskirti keturis pagrindinius aspektus: demografinè urbanizacija - gyventojų migracija iš kaimo ị miestą; teritorinè urbanizacija miesto ploto ir jo tankumo didejjimas, naujų gyvenamujų vietovių statyba; ekonominè urbanizacija - nuolatinis buvusių žemès ūkio darbuotojų persiorientavimas í miestietiškas profesijas; socialine urbanizacija - miestietiškų gyvenimo modelių (ekonominių, socialinių, kultūrinių) skverbimasis ị kaimą.

Urbanizaciją lemia objektyvi būtinybè koncentruoti ir integruoti ivairias materialinès ir dvasinès veiklos formas ir rūšis. Ji intensyvina ir efektyvina socialinius procesus, nes dideliuose miestuose socialinių politinių, ekonominių ir mokslinių techninių veiksnių, kultūrinių tradicijų, ịvairių gyventojų sluoksnių sąveika didžiausia. Urbanizacija vyksta dviem etapais. Pirmajame etape didžiausiuose miestuose dideja ekonominis ir kultūrinis visuomenès potencialas, sudarydamas sąlygas kurti svarbiausias materialines ir dvasines vertybes. Antrajame etape tas vertybes perima mažesni miestai, miesteliai ir kaimai. Būdingas Lietuvos urbanizacijos etapo bruožas yra vis spartesnis didžiųjų miestų, virstančių metropolijomis, augimas.

Šiems sudètingiems procesams valdymti būtina sukurti veiksmingą urbanistinès plètros procese dalyvaujančių struktūrų sistemą, kuri peržengtų atskirų miestų ir kaimo vietovių plètros problemas ir spręstų visos urbanistinès sistemos vystymo ilgalaikeje perspektyvoje klausimus. Kiekvienas valdymo lygmuo turi būti atsa- kingas už miestų ir kaimų teritorijų ateiti. Ministerijos, igyvendindamos sektorines politikas, turi daug aiškiau suvokti šių politikų svarbą urbanizacijos procesams, veiksmai turi būti koordinuoti, kad papildytų vieni kitus, o ne prieštarautų vieni kitiems.

\section{Valstybinis valdymo lygmuo}

Tad koks gi Lietuvos centrinès valdžios institucijų pasirengimas administruoti ir koordinuoti sudetingus urbanistinès plètros procesus? Daugelyje ịstatymų numatyta, kad pagrindines sektoriaus plètros kryptis nustato Seimas. Teritorijų planavimo ịstatymo 5 straipsnyje numatyta, kad teritorijų planavimo politikos bendrąsias kryptis nustato Seimas. Tačiau iš 14-os Seimo komitetų nè vieno komiteto pavadinime nèra žodžių teritoriju planavimas, urbanistika ar architektūra. Tradiciškai šiuos klausimus kuruoja Aplinkos apsaugos komitetas, tačiau pagrindinès šio komiteto veiklos kryptys, kuriomis vadovaujantis organizuojamas darbas, yra aplinkos apsauga, gamtos išteklių panaudojimas, miškai, medžiokle ir žvejyba. Akivaizdu, kad tarp komiteto patarejų irgi nèra architektūrinị ar urbanistinị išsilavinimą turinčių specialistų. Panaši padètis ir Vyriausybès kanceliarijos struktūroje. Iš devynių departamentų nèra né vieno, kurio pavadinime būtų minimas teritorijų planavimas, urbanistika ar architektūra. Panašiai kaip ir Seime šiuos klausimus kuruoja Aplinkos skyrius. Profesionalių architektų ar planuotojų skyriuje nèra. Urbanistika ir architektūra - tik papildomas krūvis, kaip, beje, ir Seimo komitete. 
Ministerijų lygmenyje glaudžiai tarpusavyje susijusios funkcijos, lemiančios urbanistinès plètros procesus, išskaidytos mažiausiai penkioms ministerijoms, todèl labai svarbus veiksmų koordinavimas ir dalykinis bendradarbiavimas. Formalus teisès aktų, reglamentuojančių urbanistinès pletros procesus, derinimas Vyriausybės darbo reglamento nustatyta tvarka nèra efektyvus. Svarbu vykstančius procesus suprasti ir priimti ne žinybai patogiausią, bet geriausią galimą sprendimą. Deja, dažnai apsiribojama žinybinio intereso akiračiu, nepastebint ar nesugebant pastebèti viso konteksto. Dar daugiau, imamasi administruoti svetimas sritis, kaip tai stengiasi daryti Žemès ūkio ministerija su kaimo plètra. Supratimas, kad kaimo plètra susijusi tik su žemès ūkio klausimų sprendimu, Europai buvo būdingas iki 1970 metų, tačiau Lietuvoje jis egzistuoja iki šiol. Tad nenuostabu, kad neturime parengto nè vieno kaimo teritorijos detaliojo plano ar kaimo teritorijos plètros plano, nors tokių dokumentų rengimas numatytas tiek Teritorijų planavimo, tiek Žemès įstatymuose. Remiami dažniausiai tik ūkininkai, neįvertinant fakto, kad jau dabar kaime tik apie 50 proc. gyventoju dirba žemès ūkio sferoje. Kaimo plètra - toli gražu ne vien žemès ūkis.

Daug žalos padare ir regioninès politikos formuotojų nesuvokimas, kad teritorijų planavimo dokumentai yra vienas iš svarbiausių šios politikos formavimo instrumentų. Atsakomybę, kad iki šiol dar neturime savivaldybių bendrujų planų, turi prisiimti ir ministerija, kuruojanti regioninę politiką, kuri ilgą laiką agitavo savivaldybes nerengti bendrųjų planų, priešpastatydama jiems regioninès plètros planus, dèl ko smarkiai vèluojame su savivaldybių bendraisiais planais, o kitos regioninès politikos, be tos, kuri pateikta Lietuvos Respublikos teritorijos bendrajame plane, taip ir nèra.

1998 metais sujungus Aplinkos apsaugos ir Statybos ir urbanistikos ministerijas ị vieną - Aplinkos ministeriją, nesiplètè struktūros, atsakingos už teritorijų planavimą, urbanistiką ir architektūrą, nors tuo pat metu aplinkos apsaugos sektorius nuolat plètėsi. Net ir Aplinkos ministerijos tinklalapyje, aprašant ministerijos istoriją, kalbama ne apie ministerijų sujungimą, o apie kai kurių Statybos ir urbanistikos ministerijos funkcijų perdavimą Aplinkos apsaugos ministerijai. Kadangi aplinkos apsauga ir urbanistinè pletra nuolat tarpusavyje konkuruoja, administruoti šiuos skirtingus sektorius vienoje ministerijoje yra sunku, nors padaryta ir ne taip jau mažai. Čia vèl noriu paminèti 2002 metais Seimo patvirtintą Lietuvos Respublikos teritorijos bendrąji planą, pateikusị šalies gyvenamųjų vietovių erdvinès struktūros plètros modeli, kuris, deja, taip ir liko nepastebetas daugelio valstybinių institucijų.

Būtina nagrinèti ir saugomų teritorijų administravimo ypatumus. Net 42 miestai ir miesteliai yra valstybinių parkų teritorijose, todèl šių urbanistinių struktūrų plètrą daugeliu atvejų lemia ne savivaldybè, kuriai tai priklauso daryti pagal Vietos savivaldos įstatymą, o regioninių parkų direkcijos ar Valstybinè saugomų teritorijų tarnyba prie Aplinkos ministerijos. Neturint būtino architektūrinio išsilavinimo stengiamasi reglamentuoti ir kontroliuoti architektūrinès kūrybos ir urbanistinès plètros procesus, dažnai sumaišant estetikos ir kosmetikos sąvokas.

Panaši padètis yra ir administruojant nekilnojamajjị kultūros paveldą. Kultūros vertybių apsaugos departamentas ištisus metus bandè stabdyti savivaldybių rengiamus ir iš ES struktūrinių fondų finansuojamus bendruosius planus, versdamas savivaldybes sudaryti trišales sutartis specialiesiems nekilnojamojo kultūros paveldo planams rengti, nors pagal i̇statymą šie planai turi būti rengiami ne savivaldybių, o paties departamento, kuris, deja, šiam procesui reikiamo dèmesio neskyrè.

Reikia paminèti ir apskritis, kurios 1994 metais buvo ¡kurtos tam, kad priartintų centrinès valdžios institucijas prie žmogaus, deleguojant apskritims tam tikras ministerijų funkcijas. Pravartu prisiminti apskrities viršininkui suteiktus igaliojimus, kurie nevykdomi iki šiol. Tai Apskrities valdymo ịstatymo 9 straipsnyje numatytas igaliojimas vykdyti kultūros vertybiu ir paminklų apsaugą, tvarkyti jų apskaitą ir prižiūrèti paminklotvarką bei 11 straipsnyje numatyti igaliojimai organizuoti veiklą apskričiai priskirtose saugomose teritorijose ir dalyvauti valdant kitas saugomas teritorijas. Gal verta prie šiu igaliojimo vykdymo sugrịžti ir arba pakeisti istatymo nuostatas, arba jas vykdyti.

\section{Savivaldybės lygmuo}

Niekaip nepavyksta sutvarkyti savivaldybių administracijų struktūrinių padalinių, atsakingų už teritorijų planavimo, urbanistikos ir architektūros klausimus. Šių padalinių pavadinimų ir jų atliekamų funkcijų skirtingose savivaldybèse ịvairovè didelè. Yra ir tokių savivaldybių, kur padalinių pavadinimuose nèra žodžio urbanistika ar architektūra. Aišku, ne pavadinimas lemia atliekamų funkcijų kokybę, tačiau būdingas bruožas yra tas, kad šiose struktūrose dirba labai mažai darbuotojų (vidutiniškai 4-5 specialistai), ko aiškiai nepakanka būtinoms funkcijoms atlikti. Daugelis 
šių dienų savivaldybių yra nepajėgios spręsti sudètingų, tačiau kasdieninių urbanistinès plètros klausimų. Manau, būtina kooperuoti pajegas, steigiant bendras savivaldybių įmones urbanistinès pletros klausimams stebèti, analizuoti ir spręsti.

Kadangi laisvosios rinkos reguliavimo mechanizmai neužtikrina tvarios gyvenamųjų vietovių ir visos šalies plètros, valdžios institucijos turi parengti ir vykdyti pagristą ir viešai paskelbtą urbanistinę politiką. Urbanistinès plètros valdymas turi tapti valstybès pareiga ir viena svarbiausių jos veiklos krypčių užtikrinant efektyvų ir racionalu svarbiausio nacionalinio turto - žemès naudojimą. Valstybès institucijos iš pasyvių šio proceso stebètojų turi tapti aktyviomis urbanistinès plètros proceso dalyvèmis, nes daugèja atvejų, kai savivaldybių ir stambių investuotojų interesai igijo prioritetą valstybès interesų atžvilgiu. Rengiant savivaldybių ar jų dalių bendruosius planus būtina išskirti valstybinès svarbos sprendinius, kurių igyvendinimas turi įtakos ne tik savivaldybès, bet ir šalies raidai. Tolių sprendinių keitimas turi būti leidžiamas tik atitinkamai ministerijai ar apskrities viršininkui pritarus.

Didejja spekuliacinių investicijų mastas, kai vieninteliu tikslu tampa kuo greitesnis komercinis efektas. Miestų planavimas jau remiasi ne tik teisès aktų, normatyvinių reikalavimų ar darniosios plètros principais, bet ir pačių savivaldybių sukurtu individualiu teisiniu reguliavimu, kuris dažnai prieštarauja ne tik Seimo ar Vyriausybès priimtiems teisès aktams, bet ir sveikai logikai. Dažnai planavimo varomąja jega tampa kai kurių bendruomenių noras pagerinti tik savo gyvenamąją aplinką ar padidinti privataus nekilnojamojo turto kainą.

\section{Planavimo lygmuo}

Prarandamas ir anksčiau bandytas taikyti kompleksinio planavimo principas, nes tai pačiai teritorijai rengiami keli planai. Ypač tai pasakytina apie saugomų teritorijų planavimą, kai specialieji saugomų teritorijų planai tampa svarbesni už bendruosius planus. Taip pat šiuose planuose nustatomi teritorijos tvarkymo ir naudojimo reglamentai dažnai nesutampa su saugomų teritorijų steigimo tikslais.

Neigiamos pasekmès tikètinos ir iš numatomo žemès konsolidacijos projektų rengimo bumo. Racionali žemèvalda reikalinga, tačiau šis procesas masiškai gali būti vykdomas tik parengus savivaldybių bendruosius planus, priešingu atveju, nežinodami būsimo žemès naudojimo būdo, sudarysime sąlygas neskaidriems valstybinès žemès mainams. Panašiai jau nutiko vykdant žemès reformą, kai nuosavybès teisès ị išlikusi nekilnojamajji turtą buvo atkuriamos nepaisant parengtų teritorijų planavimo dokumentų.

Nepakankamai koordinuojami urbanistinès plètros procesai kaimo gyvenamosiose vietovèse. ES struktūrinių fondų parama kaimo plètrai naudojama daugiausia žemès ūkio reikalams arba pavienių objektų statybai ir nèra efektyvi. Didmiesčių priemiestinès zonos naudojamos neracionaliai. Užstatomos rekreacijai ir žemès ūkiui naudojamos teritorijos, stengiamasi užstatyti miško parkus. Vyksta stichinès urbanizacijos procesas, nesprendžiant inžinerinès, susisiekimo, socialinès ir kitos būtinos gyvenimo kokybei užtikrinti infrastruktūros statybos klausimų.

\section{Išvadų vietoje}

Lietuvoje urbanistinès plètros procesai vyksta nekoordinuotai, nèra racionalaus urbanistinès plètros valdymo modelio. Urbanistinès plètros valdymas turi tapti valstybès pareiga ir viena iš svarbiausių jos veiklos krypčių. Daugelis savivaldybių yra nepajegios spręsti sudètingų, tačiau kasdienių urbanistinès plètros klausimų, todèl būtina kooperuoti jègas, steigiant bendras savivaldybių i̇mones urbanistinès plètros klausimams stebèti, analizuoti ir spręsti. Rengiant savivaldybių ir jos dalių bendruosius planus būtina išskirti valstybinès svarbos sprendinius, kurių igyvendinimas turi įtakos ne tik savivaldybès, bet ir šalies plètrai. Būtina užtikrinti, kad po nekoordinuotos plètros neatsirastų naujo pobūdžio problemų ar teritorinių skirtumų. Tam reikia suderinti valstybinių institucijų kompetencijas, sukurti instituciją nuolatiniam urbanistinès plètros procesui stebèti ir analizuoti, sutelkti žinių ir finansinių išteklių geriausiam galimam rezultatui pasiekti. 